\title{
SALA OPERACYJNA W ASPEKCIE JAKOŚCI POWIETRZA
}

\section{OPERATING HALL IN THE ASPECT OF AIR QUALITY}

\author{
Katarzyna Anna Haća ${ }^{a}$ Ewa Kramarz ${ }^{\mathrm{b}}$, Mariola Żukowska ${ }^{\mathrm{c}}$ \\ Zakład Radiologii Zabiegowej i Neuroradiologii, Samodzielny Publiczny Szpital Kliniczny nr 4 w Lublinie \\ ${ }^{a}$ https://orcid.org/0000-0002-5181-3066 \\ ${ }^{\mathrm{b}} \mathrm{https}: / /$ orcid.org/0000-0002-4659-5746 \\ ${ }^{c}$ https://orcid.org/0000-0002-9909-1090
}

DOI: https://doi.org/10.20883/pielpol.2020.13

\section{STRESZCZENIE}

Cel. Ocena wiedzy pracowników bloków operacyjnych na temat zagrożeń związanych z niewłaściwą jakością powietrza w sali operacyjnej.

Materiał i metody. Badania przeprowadzono wśród 70 pracowników bloków operacyjnych dwóch warszawskich szpitali. W ocenie wykorzystano metodę badań ankietowych. Ankieta zawierała 30 pytań.

Wyniki. Personel medyczny najmniejszą wiedzę prezentuje w zakresie dróg rozszerzania się patogenów ( $n=21,30 \%)$, znajomości kodów odpadów medycznych zawierających drobnoustroje i ich toksyny ( $n=17,24 \%)$. Najwięcej poprawnych odpowiedzi badani udzielili na pytania dotyczące zagrożeń wywołanych rozmowami w trakcie zabiegu operacyjnego $(n=49,70 \%)$ oraz obecności dodatkowych osób na sali operacyjnej $(n=60,86 \%)$. Z przeprowadzonych badań wynika, że świadomość personelu medycznego na temat znaczenia jakości powietrza w sali operacyjnej jest niewystarczająca.

Wnioski. 1. Badany personel medyczny posiadał wiedzę głównie na temat aspektów praktycznych związanych z pracą na sali operacyjnej. 2. Personel medyczny bloków operacyjnych w większości deklaruje chęć uczestniczenia w szkoleniach o tematyce czystości i jakości powietrza, co mogłoby znacząco zwiększyć zasób wiedzy na ten temat.

SŁOWA KLUCZOWE: sala operacyjna, klimatyzacja, jakość powietrza.

\section{Wprowadzenie}

We współczesnej medycynie, która ratuje życie ciężko chorym pacjentom, zakażenia są jednym z kluczowych powikłań najczęściej wynikających z braku przestrzegania podstawowych zasad higieny.

Czyste powietrze jest jednym z elementów bezpieczeństwa zdrowotnego pacjenta przebywającego w sali operacyjnej. Aby korzystnie zmniejszyć ryzyko zakażenia, powietrze w salach operacyjnych powinno mieć nawet kilkaset razy mniejsze stężenie zanieczyszczeń mikrobiologicznych niż powietrze zewnętrzne.

\begin{abstract}
Aim. Assessment of operational block employees' knowledge about threats related to improper air quality in the operating room.

Material and methods. The study was conducted among 70 employees of operating blocks at two Warsaw hospitals. The evaluation used the survey method. The survey contained 30 questions.

Results. Medical staff presents the smallest knowledge in the field of pathogen expansion ( $n=21,30 \%)$, knowledge of medical waste codes containing microorganisms and their toxins $(n=17$, 24\%). The respondents gave the most correct answers about the dangers caused by conversations during surgery $(n=49,70 \%)$ and the presence of additional people in the operating room ( $n=60,86 \%$ ).

Research shows that awareness of medical staff about the importance of air quality in the operating room is insufficient.

Conclusions. 1. The examined medical staff had knowledge mainly about practical aspects related to work in the operating room. 2. Medical staff of operating theaters mostly declare their willingness to participate in trainings on air purity and quality, which could significantly increase the amount of knowledge on this subject.
\end{abstract}

KEYWORDS: operating room, air conditioning, air quality.

Z uwagi na tak duże wymogi jakościowe sale operacyjne muszą być wyposażone w specjalistyczne instalacje klimatyzacyjne, dostarczające dużej ilości uzdatnionego powietrza atmosferycznego, które po przejściu przez tego typu urządzenia powinno być niemal sterylne. Konieczne jest również ograniczenie emisji zanieczyszczeń z wielu możliwych wewnętrznych źródeł. W przypadku sal operacyjnych optymalnym rozwiązaniem jest montaż stropów zapewniających laminarny nawiew uzdatnionego powietrza. 


\section{Cel}

Celem pracy była ocena wiedzy pracowników bloków operacyjnych na temat zagrożeń związanych z niewłaściwą jakością powietrza w sali operacyjnej.

\section{Materiał i metody}

Badania przeprowadzono wśród 70 pracowników (w tym 64 pielęgniarki i 6 lekarzy) bloków operacyjnych dwóch warszawskich szpitali w okresie od kwietnia do maja 2014 roku. W ocenie wykorzystano metodę badań ankietowych. Ankieta zawierała 30 pytań. Zebrane dane zostały poddane analizie za pomocą programu Microsoft Excel, który umożliwia korzystanie z edytora tekstu oraz arkusza kalkulacyjnego.

\section{Wyniki}

Z przeprowadzonych badań wynika, że personel medyczny najmniejszą wiedzę prezentuje w zakresie dróg rozszerzania się patogenów ( $n=21,30 \%)$, znajomości kodów odpadów medycznych zawierających drobnoustroje i ich toksyny ( $n=17,24 \%)$.

Najwięcej poprawnych odpowiedzi badani udzielili na pytania dotyczące zagrożeń wywołanych rozmowami w trakcie zabiegu operacyjnego ( $n=49,70 \%$ ) oraz obecności dodatkowych osób na sali operacyjnej ( $n=60,86 \%)$.

W tabeli 1 przedstawiono udzielone przez respondentów szczegółowe odpowiedzi na poszczególne pytania dotyczące czystości i jakości powietrza w sali operacyjnej.

Tabela 1. Udzielone przez badanych odpowiedzi na pytania dotyczące czystości i jakości powietrza w sali operacyjnej

Table 1. Respondents' answers about cleanliness and air quality in the operating room

\begin{tabular}{|c|c|c|c|}
\hline Pytanie/Question & Odpowiedzi/Answers & $n$ & $\%$ \\
\hline $\begin{array}{l}\text { Drogą powietrzną rozprzestrzenia się } \\
20 \% \text { patogenów/20\% of pathogens } \\
\text { spread by air }\end{array}$ & $\begin{array}{l}\text { poprawnie/correct } \\
\text { niepoprawnie/ } \\
\text { incorrectly }\end{array}$ & 21 & 30 \\
\hline $\begin{array}{l}\text { Odpady medyczne zawierające drob- } \\
\text { noustroje lub ich toksyny oznaczane są } \\
\text { kodem } 180103 / \text { Medical waste conta- } \\
\text { ining microorganisms or their toxins is } \\
\text { marked } 180103\end{array}$ & $\begin{array}{l}\text { poprawnie/correct } \\
\text { niepoprawnie/ } \\
\text { incorrectly }\end{array}$ & 53 & 24 \\
\hline $\begin{array}{l}\text { Najkorzystniejsze ciśnienie powietrza } \\
\text { w sali operacyjnej (lekkie nadciśnienie)/ } \\
\text { The most favorable air pressure in the } \\
\text { operating room (slight overpressure) }\end{array}$ & $\begin{array}{l}\text { lekkie nadciśnienie/ } \\
\text { slight overpressure } \\
\text { lekkie podciśnienie/ } \\
\text { slight underpressure }\end{array}$ & 20 & 71 \\
\hline $\begin{array}{l}\text { Wilgotność powietrza w sali operacyj- } \\
\text { nej powinna wynosić } 55 \% / \text { Humidity in } \\
\text { the operating room should be } 55 \%\end{array}$ & $\begin{array}{c}\text { właściwa/right } \\
\text { niewłaściwa/ } \\
\text { inadequate } \\
\text { nie wiem// don't know }\end{array}$ & 24 & 51 \\
\hline $\begin{array}{l}\text { Zalecana temperatura w sali opera- } \\
\text { cyjnej to } 22-25^{\circ} \mathrm{C} / \text { The recommended } \\
\text { temperature in the operating room is } \\
22-25^{\circ} \mathrm{C}\end{array}$ & nie wiem/l don't know & 22 & 31 \\
\hline
\end{tabular}

\begin{tabular}{|c|c|c|c|}
\hline \multirow{4}{*}{$\begin{array}{l}\text { Rodzaj nawiewu stosowany w salach } \\
\text { operacyjnych (laminarny)/The type of } \\
\text { ventilation used in operating rooms } \\
\text { (laminar) }\end{array}$} & laminarny/laminar & 52 & 74 \\
\hline & turbulentny/turbulent & 1 & 1 \\
\hline & $\begin{array}{c}\text { stacjonarny/ } \\
\text { stacjonary }\end{array}$ & 4 & 6 \\
\hline & nie wiem// don't know & 13 & 19 \\
\hline \multirow{4}{*}{$\begin{array}{l}\text { Właściwa liczba wymian powietrza } \\
\text { w sali operacyjnej z nawiewem laminar- } \\
\text { nym (15-30 wymian)/ } \\
\text { Correct number of air exchanges in } \\
\text { the operating theater with laminar flow } \\
\text { (15-30 exchanges) }\end{array}$} & $\begin{array}{c}\text { 8-10 wymian/ } \\
\text { 8-10 exchanges }\end{array}$ & 9 & 13 \\
\hline & $\begin{array}{l}\text { 15-30 wymian/ } \\
\text { 15-30 exchanges }\end{array}$ & 35 & 50 \\
\hline & $\begin{array}{c}45 \text { wymian/ } \\
45 \text { exchanges }\end{array}$ & 2 & 3 \\
\hline & nie wiem// don't know & 24 & 34 \\
\hline \multirow{2}{*}{$\begin{array}{l}\text { Rozmowy podczas zabiegu mają } \\
\text { wpływ na czystość powietrza w sali } \\
\text { operacyjnej/Conversations during sur- } \\
\text { gery affect the air in the operating room }\end{array}$} & $\begin{array}{l}\text { mają wpływ/ } \\
\text { they have influence }\end{array}$ & 49 & 70 \\
\hline & $\begin{array}{l}\text { nie mają wpływu/ } \\
\text { they have no influ- } \\
\text { ence }\end{array}$ & 21 & 30 \\
\hline \multirow{2}{*}{$\begin{array}{l}\text { Liczba osób obecnych w sali operacyj- } \\
\text { nej ma wpływ na jakość powietrza/The } \\
\text { number of people present in the opera- } \\
\text { ting room affects the quality of the air }\end{array}$} & $\begin{array}{c}\text { ma wpływ/ } \\
\text { it has an impact }\end{array}$ & 60 & 86 \\
\hline & $\begin{array}{l}\text { nie ma wpływu/ } \\
\text { it has no effect }\end{array}$ & 10 & 14 \\
\hline \multirow{2}{*}{$\begin{array}{l}\text { Obecność na szkoleniu o tematyce } \\
\text { jakości powietrza w bloku operacyjnym/ } \\
\text { Presence on training on air quality in } \\
\text { the operating block }\end{array}$} & obecni/prezent & 22 & 31 \\
\hline & nieobecni/absent & 48 & 69 \\
\hline $\begin{array}{l}\text { Chęć uczestniczenia w szkoleniu na } \\
\text { temat czystości i jakości powietrza }\end{array}$ & tak/yes & 63 & 90 \\
\hline $\begin{array}{l}\text { w sali operacyjnej/Willingness to parti- } \\
\text { cipate in the training on cleanliness and } \\
\text { air quality in the operating room }\end{array}$ & nie/no & 7 & 10 \\
\hline
\end{tabular}

Źródło: opracowanie własne

Source: author's own analysis

\section{Omówienie}

Na podstawie przeprowadzonych badań można stwierdzić, że personel medyczny zatrudniony w bloku operacyjnym ma częściową świadomość zagrożeń występujących w ich miejscu pracy. Respondenci mają jedynie podstawową wiedzę na temat systemu pracy klimatyzacji - pomimo znajomości konsekwencji nieprzestrzegania zasad higieny w sali operacyjnej. Dużym wyzwaniem jest podniesienie poziomu zasobu informacji w tej dziedzinie.

Jak wykazują prezentowane badania, 70\% ankietowanych nie miało nigdy do czynienia ze szkoleniem o tematyce jakości powietrza w ich miejscu pracy. Poprawa poziomu wiedzy pracowników zależy najbardziej od zaangażowania pracodawcy oraz kierowników bloków operacyjnych. Ponad $80 \%$ badanych uważa, że szkolenie takie jest potrzebne zatrudnionym w tych obiektach. Prawie 90\% osób potwierdziło chęć uczestnictwa w tego rodzaju edukacji.

Duży odsetek badanych potwierdza fakt, iż parametry mikroklimatu powietrza oraz odpowiednia jego 
jakość zapewniają komfort i bezpieczeństwo pacjentów oraz personelu. Jednak nie wiedzą oni, jak dbać o utrzymanie właściwych parametrów powietrza. Badani nie zdają sobie sprawy, jakie ciśnienie jest właściwe dla sal operacyjnych. Połowa badanych wie, ile wymian powietrza w ciągu godziny wymaga prawidłowo funkcjonująca sala operacyjna. Personel medyczny zna nazwę rodzaju nawiewu stosowanego w bloku operacyjnym, jednak nie wskazuje, jak prawidłowo dbać o właściwe jego funkcjonowanie. Z danych piśmiennictwa wynika, że jest to podstawa do osiągania dobrych wyników jakości powietrza w sali operacyjnej [1].

Ważne jest to, by pracownicy zdawali sobie sprawę, iż czyste powietrze w salach operacyjnych jest jednym z elementów bezpieczeństwa zdrowotnego pacjenta i personelu przebywającego w tym miejscu. Według danych z piśmiennictwa wynika, że około $20 \%$ czynników chorobotwórczych transmitowanych jest drogą powietrzną [2]. Niewielki odsetek badanych wskazuje prawidłową odpowiedź dotyczącą procentowego rozprzestrzeniania się patogenów w środowisku szpitalnym.

Jak dowodzą badania [3], wilgotność powietrza w sali operacyjnej powinna wynosić około $55 \%$, jednak ponad $40 \%$ badanych uważa, że suche powietrze ogranicza rozwój grzybów na powierzchniach, a kolejne $40 \%$ przyznaje się do braku informacji na ten temat.

Zatrudnieni w szpitalach powinni być motywowani przez pracodawcę do pogłębiania swojej wiedzy. Wykształcony pracownik to prawidłowe funkcjonowanie systemów szpitalnych, to również opieka nad właściwym poziomem pracy w danym miejscu, szczególnie jeżeli miejsce to wymaga specyficznego podejścia ze względu na rozwój patogenów. Działania te powinny być ukierunkowane na zmniejszenie występowania zagrożeń zdrowia oraz kształtowanie poglądów, przekonań i właściwych postaw w zakresie odpowiedzialności za prawidłowe funkcjonowanie sali operacyjnej. Konieczne jest jednak włączenie w zakres programu kształcenia wszystkich osób, których dotyczy problem.

W Polsce niewiele jest szkoleń o tematyce czystości powietrza skierowanych do personelu bloków operacyjnych. Jak dowodzą badania przeprowadzone w dwóch grupach pracowników warszawskich bloków operacyjnych, istnieje potrzeba podjęcia jak najszybszych działań zmierzających do popularyzacji wiedzy na temat aspektu jakości powietrza w blokach operacyjnych. Czyste powietrze w salach operacyjnych jest jednym z elementów bezpieczeństwa zdrowotnego pacjenta przebywającego w sali operacyjnej. W polskich salach operacyjnych standard podnosi się. W większości szpitali pojawiły się nawiewy laminarne, które pozwalają prawie w $100 \%$ niwelować drobnoustroje z powietrza [4].
Badany problem niskiej świadomości personelu medycznego, jeśli chodzi o czystość i jakość powietrza w sali operacyjnej, potwierdził się. Wielu pracowników nie zdaje sobie sprawy, jak ważna jest wiedza na ten temat. Wysoki procent badanych chciałby się dokształcić w tej dziedzinie, jednak niestety takich obowiązkowych szkoleń w miejscu zatrudnienia brakuje. Poziom informacji w tej dziedzinie można podnosić indywidualnie na konferencjach, które w większości przypadków są płatne i wymagają poświęcenia na to wolnego czasu, co później w żaden sposób nie jest wynagradzane przez pracodawców. Kolejnym zauważonym problemem jest brak świadomości pracowników, że czystość i jakość powietrza w sali operacyjnej mają wpływ na zdrowie. Z tego powodu niski poziom informacji prowadzi do pewnego rodzaju dezorganizacji pracy. Osoby zatrudnione w bloku operacyjnym skupiają się ściśle na wykonywaniu swoich czynności, często nie dbając o zasady tu panujące. Niestety w wielu miejscach przepisy te są łamane z powodu niewiedzy.

\section{Wnioski}

1. Badany personel medyczny posiadał wiedzę głównie na temat aspektów praktycznych związanych z pracą na sali operacyjnej.

2. Personel medyczny bloków operacyjnych w większości deklaruje chęć uczestniczenia w szkoleniach o tematyce czystości i jakości powietrza, co mogłoby znacząco zwiększyć zasób wiedzy na ten temat.

\section{Piśmiennictwo}

1. Charkowska A. Nowoczesne systemy klimatyzacji w obiektach służby zdrowia. Gdańsk: MASTA; 2000.

2. Złotkowska-Zapletal G. Utrzymanie czystości powietrza w bloku operacyjnym. Ogólnopol Prz Med. 2011; 9/10: 63-64.

3. Brzezińska A. Stopień wilgotności w pomieszczeniach szpitalnych. Alergologia Współczesna - Informator. 2010; 125-126.

4. Złotkowska-Zapletal G. Klimatyzacja i wentylacja na bloku operacyjnym - instalacje niezbędne. Ogólnopol Prz Med. 2013; 1: 35-38.

Artykuł przyjęty do redakcji: 27.02.2019.

Artykuł przyjęty do publikacji: 21.11.2019.

Źródło finansowania: brak.

Konflikt interesów: nie zadeklarowano.

\author{
Adres do korespondencji: \\ Katarzyna Anna Hać \\ ul. Kazimierza Jaczewskiego 8 \\ 20-954 Lublin \\ tel.: 665481148,817244154 \\ e-mail: kasiakowalczyk240@gmail.com \\ Zakład Radiologii Zabiegowej i Neuroradiologii, SPSK4 w Lublinie
}

